\title{
Addendum: Theology disrupted: Doing theology with children in African contexts
}

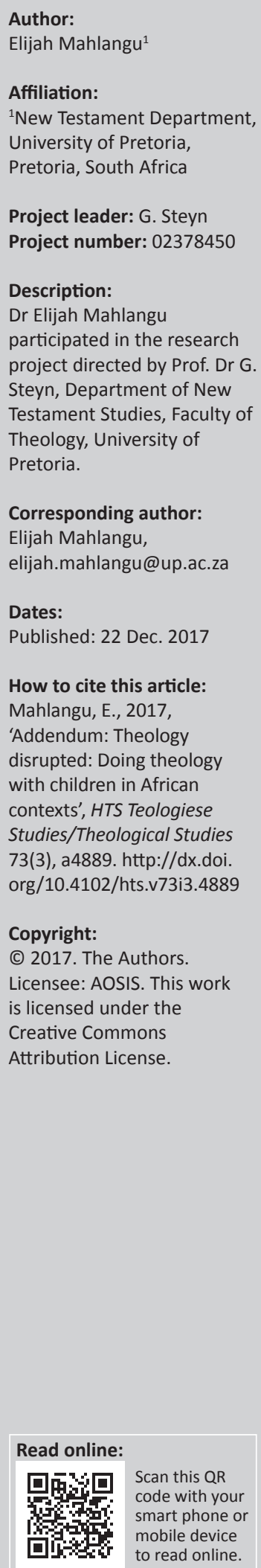

Scan this QR code with your smart phone or mobile device to read online.

In the version of this article initially published, Elijah Mahlangu inadvertently omitted acknowledging the original source for this reworked article. The acknowledgment and reference entry are hereby included.

\section{Acknowledgement}

This article is reworked from the chapter 'Child theology in Africa: A new hermeneutics?' in Welcoming Africa's children - Theological and ministry perspectives.

\section{Reference}

Mahlangu, E. \& Grobbelaar, J., 2016, 'Child theology in Africa: A new hermeneutics?', in J. Grobbelaar \& G. Breed (eds.), Welcoming Africa's children - Theological and ministry perspectives, pp. 88-114, AOSIS, Cape Town. http://www.dx.doi.org/10.4102/aosis.2016. waccs13.03

This addendum does not alter the study's findings of significance or overall interpretation of the study results. The author apologises for any inconvenience caused. 